\title{
Insubsistente a Tese de um Conceito Federal de Desenvolvimento da Comunidade
}

\author{
Yves De Oliveira \\ (Delegado do Brasil à V Reunião \\ Interamericana de Museus)
}

Não encontramos fundamento lógico e científico para um «conceito federal» do desenvolvimento da comunidade. Não nos parece que, realmente exista um "conceito federal" concernente ao assunto. E' o velho ranço federalista, ainda dominando as Américas, quando êle já está superado, pelo menos. para o presente, no pensamento político brasileiro.

O art. 28 da Constituição Brasileira, que se refere à autonomia municipal situa no mesmo plano de govêrno as três esferas políticas: a União, os Estados-membros e os Municípios. Portanto, o conceito de desenvolvimento da comunidade não pode ser fixado na esfera mais distante de govêrno em relação aos problemas imediatos do povo. Não se pode conceber mais, diante da evolução do Direito Público e da Sociologia modernos, essa anomalia conceitual. $\mathrm{O}$ desenvolvimento da comunidade se processa igualmente, na interdependência das três esferas de govêrno, principalmente na do Município com maior intensidade.

Se o conceito federal de govêrno está superado, muito mais o de estritamente referente ao de desenvolvimento da comunidade. Sendo a comunidade um todo, não seria aconselhável se admitir que a mesma pudesse ser encarada de modo fracionado, como aconteceria face à aceitação de um "conceito federal" de comunidade como se encontra no temário do II Seminário Universitário Interamericano de Estudos Municipais.

\section{CONCEITO DE COMUNIDADE}

O eminente professor Arthur Hillman, no seu livro sôbre esta matéria, assinala com clarevidência $\left({ }^{1}\right)$ : “A palavra comunidade não é propriedade de ninguém e é usada em vários sentidos.»

Poderiamos dizer algo que se repete a todo instante, a Comunidade como sendo um grupo localizado de pessoas.

(1) "Organização da Comunidade e Planejamento" Livraria AGIR Editôra, Rio de Janeiro, 1956, pág. 19. 
Recorrendo novamente aos conceitos de Arthur Hillman, um autor insuspeito porque Norte Americano, acrescentariamos (2): «Os seus limites não são sempre (o gripo é nosso) os de um municípios ou de qualquer outra divisão politica do território, como vários estudos aqui citados o demonstram. A unidade econômica e social funciona dentro de uma área, pode (o grifo é nosso) transcender os limites traçados pela divisão teritorial.»

O grande equivoco talvez da idéia contida no temário dêste Seminário está claramente contida no livro do escritor e professor de Sociologia de Chicago, que denuncia essa infeliz tendência de valorização cada vez maior, até certo ponto, do govêrno central nos Estados Línidos da América do Norte.

Senão vejamos essa manifesta tendência contra a qual pedimos licença a essa douta Assembléia de estudiosos para divergir (3) : «O govêrno central é chamado a assumir responsabilidade junto a comunidades que não podem satisfazer às suas próprias necessidades. O papel do govêrno, tanto federal como estadual, é, nos Estados Unidos, o de suprir preenchendo as lacunas; porém há tendência em ampliar a função do govêrno central. Essa centralização de podêres, contudo, não elimina a possibilidade de ação das comunidades ou municipios. Por mais ativo que seja o govêrno central, a maneira de vive das comunidades segue sem interferência."

Desejamos, apenas, apontar inquestionàvelmente, a fonte talvez dessa inspiração equívoca, no campo da doutrina Norte Americana, qual seja a de estabelecer um conceito federal de desenvolvimento da comunidade. Contra essa tendência que consideramos equivoca, nos manifestamos de modo claro, porque não reconhecemos como exato, proclamado pela ciência até agora, a tranqüila aceitação dessa tese. Ela contraria, fundamentalmente, o próprio conceito de Comunidade e da doutrina municipalista na sua essência, valorizadora de um novo conceito político que valorize ao máximo o principio da descentralização do Estado Moderno com raizes no Municipio para solução dos problemas imediatos de todo homem e de tôda comunidade.

Inexiste, portanto, um conceito especificamente federal de comunidade.

\section{CONCLUSÃO}

Ante o exposto sintèticamente focalizado, concluimos pela não aceitação no campo da ciência, de um conceito federal do desenvolvimento de comunidade, por considerar que ela é um todo, em tôdas os seus aspectos conceituais. com maior área de ação na vida municipal.

San Diego, 16 de outubro de 1960.

(2) Obra citada, pág. 21 .

(3) Obra citada, pág. 23 . 